\title{
Field study on bovine paratuberculosis using real-time PCR and liquid culture for testing environmental and individual fecal samples implemented in dairy cow management
}

\author{
A. K. Schwalm, ${ }^{1 *}$ ๑ C. Metzger-Boddien, ${ }^{2}$ G. Seemann, ${ }^{3}$ J. Mandl, ${ }^{3}$ A. Obiegala, ${ }^{4}$ M. Pfeffer, ${ }^{4}$ and R. Sting ${ }^{1}$ \\ ${ }^{1}$ Chemical and Veterinary Investigations Office, Stuttgart, Fellbach D 70736, Germany \\ ${ }^{2}$ gerbion $\mathrm{GmbH}$ and Co. KG, Kornwestheim D 70806, Germany \\ ${ }^{3}$ Animal Health Service, Baden-Wuerttemberg Animal Diseases Fund, Fellbach D 70736, Germany \\ ${ }^{4}$ Institute of Animal Hygiene and Veterinary Public Health, University of Leipzig, Leipzig D 04103, Germany
}

\section{ABSTRACT}

Bovine paratuberculosis (Johne's disease) is a bacterial, chronic, and wasting intestinal disease caused by Mycobacterium avium ssp. paratuberculosis (MAP). Johne's disease causes severe losses in dairy farm productivity and is also suspected to be a potential trigger for Crohn's disease in humans. The fecal-oral infection of MAP to neonates is recognized as an important within-herd transmission route. Our objective was to recommend diagnostic methods for herds with suspected paratuberculosis requiring fast results, as well as for herds with breeding programs or others that aim at being nonsuspected of paratuberculosis infection. We determined a period of $8 \mathrm{wk}$ from sampling to diagnostic findings suitable for testing of cows during the dry period. We therefore tested environmental and individual fecal samples with one rapid and one highly sensitive diagnostic method. Environmental samples (boot swabs) were taken as a first step in 3 herds and tested using a DNA extraction protocol for feces and subsequent real-time PCR (referred to as fecal PCR). Additionally, cultivation in liquid medium for 6 wk was performed and verified with real-time PCR (referred to as liquid culture). Automation of DNA extraction based on magnetic beads and the PCR setup was performed with pipetting robots. As a result, we successfully detected MAP in boot swabs of all herds by both methods. In a second step, 245 individual fecal samples from the 3 herds were examined using also fecal PCR and liquid culture. The results obtained by fecal PCR were compared with detection of MAP using cultivation in liquid medium for 6 wk. Testing individual cows, we identified MAP-specific DNA in 53

Received September 5, 2018.

Accepted August 21, 2019.

*Corresponding author: Katharina.Schwalm@cvuas.bwl.de fecal samples using the liquid culture. Using fecal PCR, we revealed 43 positive samples of which 39 also tested positive in the liquid culture, revealing MAP-positive cows in all 3 herds. The fecal PCR procedure allows rapid detection of MAP-specific DNA with $74 \%$ of the sensitivity of liquid culture. For the purpose of testing with maximal sensitivity, cultivation in liquid medium is recommended. Cultivation of MAP in liquid medium M7H9C means a significant time gain in comparison to cultivation on solid media, which requires twice as much time. Thus, this testing fits within the 6- to 8-wk dry period of gravid cows and provides test results before calving, a prerequisite to prevent fecal-oral transmission to newborn calves.

Key words: liquid medium M7H9C, real-time PCR, dry period, Mycobacterium avium ssp. paratuberculosis

\section{INTRODUCTION}

Bovine paratuberculosis (Johne's disease) is a bacterial, chronic, and wasting intestinal disease caused by Mycobacterium avium ssp. paratuberculosis (MAP), which is prevalent throughout many countries and leads to high losses in dairy production (Nielsen, 2009). This disease has negative effects on health, milk yield, and slaughter value of dairy cows, which are prone to develop paratuberculosis when their age exceeds 5 yr on average (Lombard, 2011; Fecteau, 2018).

Mycobacterium avium ssp. paratuberculosis is also suspected to be involved in the development of ulcerative colitis, Crohn's disease, and as a complication in colorectal cancer in humans (Liverani et al., 2014; Garvey, 2018; Pierce, 2018). For this reason and due to the serious long-term economic impact, bovine paratuberculosis is an important global issue and control programs are considered indispensable for dairy farming and food hygiene management (Bakker, 2014).

Besides hygiene and biosecurity measures, removal of MAP-infectious cows from the herd is crucial for para- 
tuberculosis control. Therefore, diagnostic methods that are feasible in laboratory routine, rapid, and sensitive for MAP detection are required. The determination of the herd status by means of environmental fecal samples is one important tool to meet these requirements (Raizman et al., 2004; Eisenberg et al., 2013; Hahn et al., 2017). Despite this diagnostic progress and advances in DNA extraction procedures and PCR analyses (Selim and Gaede, 2012; Timms et al., 2015; Schwalm et al., 2018), the chronic course of the disease, intermittent fecal shedding of the pathogen, and the presence of latently infected cattle hamper diagnosis of Johne's disease (Whittington and Sergeant, 2001).

Due to its higher sensitivity compared with the commonly used solid medium, cultivation of MAP from fecal samples in liquid medium is a promising method to decrease the number of latently infected cattle that pose a hidden source of infection. Cultivation in liquid medium based on Middlebrook 7H9 broth is highly sensitive, provides reliable results in half the time of solid medium, can be produced with low costs, and has the potential to be automatable for laboratory routine (Pozzato et al., 2011; Plain et al., 2015; Schwalm et al., 2018). Therefore, liquid culture is an alternative to solid medium and can serve as reference method for the detection of paratuberculosis (Whittington, 2009).

Our objective was to recommend diagnostic methods for identification of infectious cows in suspected and nonsuspected paratuberculosis herds within a maximum time period of $8 \mathrm{wk}$. This complies with the dry period of gravid cows before birth. Identification of MAP shedding of gravid cows before calving is decisive to prevent one main route of infection, the fecal-oral transmission of MAP from the dams to newborn calves (Donat et al., 2016; Al-Mamun et al., 2017).

For this purpose, we sampled boot swabs in a first step and individual fecal samples in a second step from dairy cows in 3 herds, which had previously been serologically tested as positive. Extraction of DNA from boot swabs/feces and subsequent real-time PCR (referred to as fecal PCR) were compared with cultivation of MAP in the liquid medium M7H9C for $6 \mathrm{wk}$ followed by subsequent verification by real-time PCR (referred to as liquid culture). Both methods had been previously validated for bovine fecal samples (Schwalm et al., 2018) and were applied here in a field study to check their feasibility and performance.

\section{MATERIALS AND METHODS}

\section{Dairy Herds and Samples}

Four boot swabs per herd were taken, giving a total of 12 boot swabs in 3 different herds (herd A, B, and
C) in the state of Baden-Wuerttemberg, Germany, from June to July 2017. In addition to boot swabs, a total of 245 individual fecal samples were taken from the 3 herds. Fecal samples were taken in herd A from 100 of 390 dairy cows, in herd B from all 74 dairy cows, and in herd C from 71 of 91 dairy cows. All herds were previously confirmed to be MAP-positive by ELISA using blood samples from 2014 to 2017, revealing a herd prevalence of 10 to $14 \%$. In addition, the serological results were verified in each herd by cultivation of MAP from individual fecal samples on solid culture (Herrold's egg yolk medium).

\section{Procedures in the Laboratory}

First Step: Testing of Environmental Fecal Samples (Boot Swabs). The first step in paratuberculosis diagnostics aims at the detection of the pathogen in the herd's environment using boot swabs taken from areas with high cow traffic [i.e., the milking parlor, the holding pen, and the main alleyway (Donat et al., 2011; Eisenberg et al., 2013; Hahn et al., 2017)]. In detail, plastic boot covers were pulled over rubber boots when entering the stable. In each area of sampling, a fresh pair of boot swabs (Hele, Heilsbronn, Germany) was pulled over the plastic boot covers. For transportation, boot swabs were put in $250-\mathrm{mL}$ plastic tubes with a screw cap. We stored the boot swabs from each sampling site (4 boot swab pairs in total) at $7^{\circ} \mathrm{C}$ until the next day for further processing in the laboratory.

Second Step: Testing of Individual Fecal Samples. Fecal samples from cattle older than 24 mo were taken from the rectum of each cow using fresh disposable plastic gloves. The fecal samples were stored at $7^{\circ} \mathrm{C}$ until the next day after an aliquot of $1 \mathrm{~g}$ had been saved for DNA extraction and $2 \mathrm{~g}$ for cultivation of MAP in liquid medium M7H9C (Schwalm et al., 2018). Remaining feces were stored at $-20^{\circ} \mathrm{C}$.

\section{Two Methods for Testing}

Fecal PCR and liquid culture were performed for boot swabs as well as for individual fecal samples.

DNA Extraction from Boot Swabs and Individual Fecal Samples for Fecal PCR. Extraction of DNA from boot swabs and individual fecal samples for fecal PCR was carried out with the NukEx Mag Extreme SC extraction kit, G05025 (version 1.4/11.01.2018, gerbion, Kornwestheim, Germany) according to the manufacturer's instructions.

We prepared the boot swabs for the DNA extraction procedure as follows: the boot swabs were fixed with sterile forceps and cut with sterile scissors. Three 
grams of the pieces was placed into a 50-mL centrifugation tube (Sarstedt, Nümbrecht, Germany), filled with $20 \mathrm{~mL}$ distilled water, and mixed thoroughly. After sedimentation for $20 \mathrm{~min}$ at room temperature, the supernatant was transferred completely into a new 50$\mathrm{mL}$ centrifugation tube. Subsequently, the tubes were centrifuged at $3,000 \times g$ for 5 min at room temperature, the supernatants discarded, and the pellets re-suspended with $2 \mathrm{~mL}$ of distilled water for further extraction procedures (FLI, 2016).

Extraction of DNA from fecal samples was carried out by mixing $1 \mathrm{~g}$ of feces with $2.5 \mathrm{~mL}$ of distilled water in a $15-\mathrm{mL}$ centrifugation tube (Greiner Bio-One, Frickenhausen, Germany). After the tubes were centrifuged at $8,000 \times g$ for $5 \mathrm{~min}$ at $20^{\circ} \mathrm{C}$, the supernatant was discarded. Then, $600 \mu \mathrm{L}$ of extraction buffer (EX1) was added and homogenization was performed with the TissueLyser (MM400, Retsch, Haan, Germany) 3 times $\times 4 \mathrm{~min}$ at $30 \mathrm{~Hz}$. After a short centrifugation step with $25,000 \times g$ at $20^{\circ} \mathrm{C}, 600 \mu \mathrm{L}$ of extraction buffer (EX2) was added and mixed briefly. Subsequently, the tubes were centrifuged at $3,000 \times g$ for $5 \mathrm{~min}$ at $20^{\circ} \mathrm{C}$ and $800 \mu \mathrm{L}$ of supernatant was subjected to DNA extraction, based on magnetic beads including inhibitor removal, wash and elution steps, and processed on a King-Fisher Flex device (Thermo Fisher Scientific, Schwerte, Germany).

Cultivation of Boot Swabs and Individual Fecal Samples Using Liquid Medium M'7H9C. We used the protocol for the preparation of feces according to Whittington et al. (1999) for boot swabs and individual fecal samples for subsequent cultivation of MAP in the liquid medium M7H9C, based on Middlebrook 7H9 broth (Whittington et al., 2013). In detail, 3 g from each boot swab pair was mixed with $20 \mathrm{~mL}$ of isotonic saline solution or $2 \mathrm{~g}$ of fecal sample was mixed thoroughly with $10 \mathrm{~mL}$ of isotonic saline solution in a $50-\mathrm{mL}$ centrifugation tube followed by a decontamination step for a total of $96 \mathrm{~h}$ with $25 \mathrm{~mL}$ of $0.9 \%$ hexadecylpyridinium chloride solution (Sigma, Steinheim, Germany) and with the addition of $1 \mathrm{~mL}$ of ANV suspension [amphotericin B $(50 \mu \mathrm{g} / \mathrm{mL}$, Sigma), nalidixic acid $(100 \mu \mathrm{g} / \mathrm{mL}$, Sigma), and vancomycin (100 $\mu \mathrm{g} /$ mL, Sigma)] (Whittington et al., 1999; Schwalm et al., 2018). In a further step, the supernatant was discarded and $100 \mu \mathrm{L}$ of the sediment was transferred into each of 3 tubes of the liquid medium M7H9C per sample and mixed thoroughly.

After an incubation period of 6 wk at $37^{\circ} \mathrm{C}$, we took $300-\mu \mathrm{L}$ aliquots from each tube for storage at $-20^{\circ} \mathrm{C}$ until further processing. For the DNA extraction of each aliquot we used the NukEx Mag RNA/DNA kit G05012 (version 1.2/17.12.2015, gerbion), as described by Schwalm et al. (2018).

\section{Real-Time PCR Procedures}

Each time after extraction of DNA from the boot swabs, the individual fecal samples and the 3 aliquots of the liquid medium M7H9C per fecal sample, the diarellaMAP vet real-time PCR G01099 (version 1.3/10.02.2016, gerbion) was used for detection of MAP-specific DNA as described by the manufacturer. The diarellaMAP vet real-time PCR targets the MAP gene insertion sequence 900 (IS900) for sensitive detection of MAP-specific DNA (Herthnek and Bolske, 2006). This assay is performed as a duplex PCR detecting an internal amplification control.

A total of $20.5 \mu \mathrm{L}$ of reaction mix was used for the PCR setup, containing $16 \mu \mathrm{L}$ of master mix ready for use, $0.5 \mu \mathrm{L}$ of internal control (all provided by the kit), and $4 \mu \mathrm{L}$ of extracted DNA. The PCR run was carried out under the following conditions: initial denaturation step $\left(95^{\circ} \mathrm{C}, 5 \mathrm{~min}\right)$, followed by a 2 -step protocol $(45$ cycles) including a denaturation step $\left(95^{\circ} \mathrm{C}, 10 \mathrm{~s}\right)$ and an annealing/elongation step $\left(60^{\circ} \mathrm{C}, 40 \mathrm{~s}\right)$.

All PCR assays (i.e., using either the DNA extracted from boot swabs or individual fecal samples, and from each of 3 liquid medium aliquots per fecal sample), were tested in duplicate, as is usually carried out in MAP diagnostics (Herthnek and Bolske, 2006; Plain et al., 2014; Sting et al., 2014). The reason for performing the PCR assays in duplicate is to improve the probability of detection of the target gene (Herthnek and Bolske, 2006). The PCR runs were carried out on the real-time PCR cycler CFX96 (Bio-Rad Laboratories, Munich, Germany) and data evaluated with the CFX manager Software Version 3.1 (Bio-Rad Laboratories).

According to Plain et al. (2014), a fecal sample was considered positive in fecal PCR if at least one specific PCR signal was detected. Similarly, a sample was considered positive in liquid culture if at least in one tube a specific PCR signal was detected (Pozzato et al., 2011). The fecal PCR had been validated and certified for feces by the Friedrich-Loeffler Institut, Federal Research Institute for Animal Health (diarellaMAP vet real-time PCR Kit, G01099-96, version 1.3/10.02.2016, marketing authorization number FLI-B673) setting the cut-off value at cycle threshold (Ct) 40. The cut-off value for the liquid culture was set at Ct 38 (Schwalm et al., 2018). As specified by Schwalm et al. (2018), real-time PCR signals yielding $\mathrm{Ct}$ values of $\geq 33$ were categorized as weak signals and $\mathrm{Ct}$ values $<33$ as moderate to strong signals.

\section{Statistical Analyses}

Fisher's exact test was used for statistical comparisons of positive and negative results obtained from fecal 
Table 1. Detection of Mycobacterium avium ssp. paratuberculosis (MAP) in environmental fecal samples (boot swabs, $\mathrm{n}=12$ ) originating from 3 herds using real-time PCR for detection of MAP-specific DNA (fecal PCR), and cultivation in the liquid medium M7H9C for 6 wk verified by PCR (liquid culture)

\begin{tabular}{|c|c|c|c|c|c|c|c|}
\hline Item & $\begin{array}{l}\text { No. of } \\
\text { samples } \\
\text { tested }\end{array}$ & \multicolumn{3}{|c|}{ Fecal PCR } & \multicolumn{3}{|c|}{ Liquid culture } \\
\hline Herd A & 4 & 0 & $4(100)$ & 0 & 0 & 0 & $4(100)$ \\
\hline Herd B & 4 & 0 & $1(25)$ & $3(75)$ & 0 & 0 & $4(100)$ \\
\hline
\end{tabular}

${ }^{1}$ Cycle threshold $\geq 33$.

${ }^{2}$ Cycle threshold $<33$.

PCR and liquid culture. Additionally, 2 groups were defined (group 1: 1 out of 3 culture tubes positive; group 2: 2 or 3 out of 3 culture tubes positive) and compared according to their strength of the PCR signal [again group as weak ( $\mathrm{Ct} \geq 33$ ), and moderate to strong ( $\mathrm{Ct}$ value $<33$ )], using the same test. The Fisher's exact test (2-tailed) was carried out with the program GraphPad Prism 4 (GraphPad Software Inc., San Diego, CA).

The Spearman's rank correlation coefficient was calculated to determine how well the rank between $\mathrm{Ct}$ values of fecal PCR and $\mathrm{Ct}$ values of $\mathrm{PCR}$ after cultivation in liquid medium correlate. The Spearman's rank correlation coefficient $\left(\mathbf{r}_{\mathrm{s}}\right)$ was computed with the Predictive Analytics SoftWare Statistics, full version 22.0 (IBM SPSS, IBM Corporation, Armonk, NY). The significance level was set at $P<0.05$ for each test.

\section{RESULTS}

\section{First Step: Detection of MAP in Environmental Fecal Samples (Boot Swabs)}

We identified MAP in all boot swabs taken from the milking parlors, waiting pens, and main alleyways, except for one sample from the milking parlor in herd C (Table 1). In contrast to the fecal PCR, where all samples yielded $\mathrm{Ct}$ values of $>29$, in liquid culture most of the samples yielded $\mathrm{Ct}$ values $<25$ with only one sample returning a Ct value of $>29$ (data not shown).

\section{Second Step: Detection of MAP in Individual Fecal Samples}

We confirmed the presence of MAP in all 3 herds by testing a total of 245 individual fecal samples from dairy cows (herd A 100, herd B 74, herd C 71 fecal samples) using both the fecal PCR and liquid culture (Table 2). In detail, in herd A and in herd C MAP was detected in more individual fecal samples by liquid culture than using fecal PCR; however, in herd B fecal PCR detected one more sample that had not been detected in liquid culture (Table 2). In total, 53 of 245 individual fecal samples revealed positive results in liquid culture and 43 in fecal PCR. The results of fecal PCR and liquid culture did not differ significantly (Fisher's exact test, $P=0.306$, Table 3$)$. Using liquid culture as reference method, we calculated a sensitivity of $73.58 \%$ (95\% CI: 59.67 to 84.74) for fecal PCR.

With regard to positive samples, the $\mathrm{Ct}$ values of fecal PCR and the Ct values of PCR after cultivation were well related $\left(P<0.001, \mathrm{r}_{\mathrm{s}}=0.92\right)$. However, 14 and 4 samples, respectively, revealed either only positive results by liquid culture or by fecal PCR (Table 3).

Table 2. Detection of Mycobacterium avium ssp. paratuberculosis (MAP) in individual fecal samples originating from 3 herds using real-time PCR for detection of MAP-specific DNA (fecal PCR) and cultivation in the liquid medium M7H9C for 6 wk verified by PCR (liquid culture)

\begin{tabular}{|c|c|c|c|c|c|}
\hline Item & $\begin{array}{c}\text { No. of } \\
\text { samples tested }\end{array}$ & \multicolumn{2}{|c|}{ Fecal PCR } & \multicolumn{2}{|c|}{ Liquid culture } \\
\hline Herd B & 74 & $8(11.0)$ & $66(89.0)$ & $7(9.5)$ & $67(90.5)$ \\
\hline Herd C & 71 & $13(18.0)$ & $58(82.0)$ & $16(22.5)$ & $55(77.5)$ \\
\hline Total no. (\%) & $245(100)$ & $43(17.5)$ & $202(82.5)$ & $53(22.0)$ & $192(78.0)$ \\
\hline
\end{tabular}


Table 3. Detection of Mycobacterium avium ssp. paratuberculosis (MAP) in individual fecal samples using real-time PCR for detection of MAP-specific DNA (fecal PCR) and cultivation in the liquid medium M7H9C for 6 wk verified by PCR (liquid culture)

\begin{tabular}{lccc}
\hline & & \multicolumn{2}{c}{ Liquid culture } \\
\cline { 3 - 4 } Item & $\begin{array}{c}\text { Total no. } \\
(\%)\end{array}$ & $\begin{array}{c}\text { No. of } \\
\text { positive samples }(\%)\end{array}$ & $\begin{array}{c}\text { No. of } \\
\text { negative samples }(\%)\end{array}$ \\
\hline Fecal PCR & $43(17.5)$ & $39(15.9)$ & $4(1.6)$ \\
Positive samples & $202(82.5)$ & $14(5.7)$ & $188(76.8)$ \\
Negative samples & $245(100)$ & $53(21.6)$ & $192(78.4)$ \\
Total no. (\%) & & & \\
\hline
\end{tabular}

During the incubation period of 6 wk, no obvious contamination of liquid medium was detected.

Furthermore, a closer look at the samples positively tested in liquid culture revealed that detection of MAP succeeded in $25(47 \%)$ samples when considering the result of only the first culture tube, in an additional $12(23 \%)$ samples when considering the first and the second tube, and in a further $16(30 \%)$ samples when considering all 3 inoculated tubes.

In view of the 53 fecal samples tested positive in liquid culture, which equals 97 positive culture tubes, 40 tubes were tested positive with a weak PCR signal after cultivation and 57 tubes with a moderate to strong PCR signal after cultivation (Table 4). The strength of the PCR signal after cultivation is significantly different between group 1 ( 1 out of 3 culture tubes positive) and group 2 ( 2 or 3 out of 3 culture tubes positive; Fisher's exact test; $P=0.001$, Table 4 ).

\section{DISCUSSION}

Diagnostic methods for detection of MAP-shedding cattle have recently been improved considerably. This has been achieved by refinement of real-time PCR-based procedures for fecal samples and the use of highly sensitive cultivation of MAP in liquid medium (Fock-ChowTho et al., 2017; Prendergast et al., 2018; Schwalm et al., 2018). These methodological improvements have led to time gain and an enhanced sensitivity in detection of MAP. Based on this, the improvements of PCR procedures and cultivation in liquid media make detection of this pathogen in herds with low prevalence feasible at reasonable costs (Pozzato et al., 2011). Thus, in our study we implemented recently commercially available test kits for detection of MAP in feces (fecal PCR) and in addition cultivation of the pathogen in the liquid medium M7H9C (Whittington et al., 2013; Plain et al., 2014, 2015; Schwalm et al., 2018). We succeeded in performing fecal PCR in a weekly routine setting, whereas the liquid culture procedure took 6 wk finalized by detection of MAP-specific DNA by real-time PCR.

A well-known strategy for detection of MAP in dairy herds is testing of boot swabs taken from areas mostly frequented by the cows (Hahn et al., 2017). Liquid medium has been used to our knowledge for the first time for this purpose. In our study, all but one boot swab revealed positive results in fecal PCR and as well in liquid culture, associated with a herd prevalence of 6 to $14 \%$ (fecal PCR) and 8 to $18 \%$ (liquid culture) evaluated by testing of individuals.

A closer look at the data shows that the liquid culture yielded stronger PCR signals after cultivation of MAP than fecal PCR, which is evidence for multiplication of the MAP bacteria. In contrast to these findings, Ramovic et al. (2019) reported negative results when testing environmental samples (dust) for MAP using liquid medium, but positive results when using realtime PCR. Furthermore, in the study by Ramovic et

Table 4. Comparison of the number of culture tubes positively tested with the strength of signal of the PCR used for the liquid medium M7H9C after cultivation of $6 \mathrm{wk}^{1}$

\begin{tabular}{|c|c|c|c|}
\hline Item & $\begin{array}{c}\text { No. of positive } \\
\text { culture tubes }\end{array}$ & $\begin{array}{c}\text { No. of samples } \\
\text { with weak } \\
\text { signal }^{2}(\%)\end{array}$ & $\begin{array}{l}\text { No. of samples } \\
\text { with moderate } \\
\text { to strong } \\
\text { signal }^{3}(\%)\end{array}$ \\
\hline 2 or 3 out of 3 culture tubes positive (group 2) & 72 & $21(52)$ & $51(90)$ \\
\hline Total & 97 & $40(100)$ & $57(100)$ \\
\hline
\end{tabular}

${ }^{1}$ For each sample, 3 culture tubes were inoculated.

${ }^{2}$ Cycle threshold $\geq 33$.

${ }^{3}$ Cycle threshold $<33$. 
al. (2019), real-time PCR also proved to be as sensitive as cultivation of MAP in liquid medium. These authors ascribe this phenomenon to pretreatment procedures for decontamination before cultivation. Nevertheless, our results suggest the use of boot swabs tested for MAP using real-time PCR or cultivation in liquid medium as a sensitive and reliable tool for identification of the MAP status in herds suspected of paratuberculosis. In case of detection of MAP-specific DNA in boot swabs, the second step aiming at detection of MAPinfectious cows has proved to be appropriate to reveal individual MAP shedders. Thereby, we succeeded in detection of MAP-specific DNA using fecal PCR in about three-quarters of the samples that had been positively tested in the liquid medium. Divergent from these results, recent comparative studies on detection of MAP report on high sensitivity values of about $90 \%$ for fecal PCR in comparison to cultivation of MAP in liquid medium systems (Fock-Chow-Tho et al., 2017; Prendergast et al., 2018; Schwalm et al., 2018). However, these validation studies have limitations due to the long-term storage of the fecal samples at freezing temperatures in comparison with direct investigations in field studies (Prendergast et al., 2018). This practice is detrimental to survival of MAP impairing multiplication, consequently decreasing the sensitivity of detection of the pathogen by culture rather than by PCR (Raizman et al., 2011; Prendergast et al., 2018). This is evidenced in our study by detection of additional $26 \%$ MAP-shedding cows in liquid culture tested immediately after sampling. In total, the fecal PCR resulted in a sensitivity of $74 \%$ compared with liquid culture. This discrepancy of results emphasizes the importance of methodological comparative studies in the field.

High sensitivity of detection of MAP in liquid culture is favored by viable and multiplying MAP bacteria, inoculation in triplicate, and final testing of each tube in duplicate by real-time PCR. Inoculation of 3 culture tubes per sample doubles the sensitivity of MAP detection when using 3 instead of only one culture tube and might explain the lower sensitivity of fluid culture in comparison to real-time PCR described by Laurin et al. (2015), using only one culture tube per sample. This effect has also been reported by Schwalm et al. (2018); hence, the approach using 3 culture tubes per sample is recommended.

In addition, the strength of the PCR signal after cultivation differed depending on the number of positive culture tubes per sample. This means that the more culture tubes per sample proved MAP-positive, the higher the PCR signals of samples after cultivation in liquid medium M7H9C. Considering that real-time PCR is suitable for pathogen quantification, the higher the signal, the more MAP bacteria are shed via feces (Laurin et al., 2015; Schwalm et al., 2018).

Real-time PCR used for detection of MAP in fecal samples provide $\mathrm{Ct}$ values that can be quantified on the basis of standard regression curves, and hence contributes to closing methodical gaps that hamper prevention and control of bovine paratuberculosis (Barkema et al., 2018).

Accurate detection of positive samples (i.e., test sensitivity and test specificity) are important parameters for a mathematical model serving as basis for the design of an effective control program ( $\mathrm{Lu}$ et al., 2008; Al-Mamun et al., 2017). Furthermore, it must be kept in mind that control of bovine paratuberculosis focuses on the reduction of the herd's pathogen load, since eradication of MAP is not a feasible goal (Collins et al., 2010; Al-Mamun et al., 2017). Nevertheless, in case of negative PCR results in low prevalence herds, liquid culture should be employed for confirmatory purposes. This assessment is corroborated by comparative studies including fecal PCR and cultivation in liquid medium (Fock-Chow-Tho et al., 2017; Prendergast et al., 2018; Schwalm et al., 2018).

Regarding negative results, our study revealed a consistency of $98 \%$ in both methods. The phenomenon of inconsistent results showing positive signals in realtime PCR but negative results in culture have also been reported by Prendergast et al. (2018). These authors attribute this phenomenon to a decrease of viable MAP bacteria due to the decontamination protocol for fecal samples. This especially concerns the reduction of cultivated bacteria in fecal samples from cows shedding the pathogen in low numbers (Reddacliff et al., 2003; Johansen et al., 2006).

The test parameters sensitivity and specificity characterizing detection of MAP in feces based on culture and PCR are affected by contaminations and inhibitors (Prendergast et al., 2018). In this context, especially fecal PCR assays and liquid culture systems based on indicators for growth of mycobacteria are prone to unspecific signals (Whittington et al., 2013). Therefore, subsequent testing using MAP-specific PCR including an internal amplification control is essential for fecal PCR and verification of growth of MAP in liquid media (Whittington et al., 2013; Prendergast et al., 2018). Although contamination of fecal culture cannot be excluded due to a high load of microbial fecal flora (Whittington, 2009), in the presented study no visible contamination of liquid culture was observed during the incubation period of $6 \mathrm{wk}$.

Accurate, time- and cost-effective testing of environmental samples and feces from individual cows are the pillars of paratuberculosis diagnostics and control pro- 
grams in dairy farming (Laurin et al., 2015; Barkema et al., 2018). Detection of pathogen shedding is of particular value in the prevention of the spread of bovine paratuberculosis from persistent infected cows by the fecal-oral route. This especially affects transmission of MAP-shedding adults to susceptible calves (Marcé et al., 2011) and the between-herd transmission caused through purchase of infected animals or participation in auctions (Barkema et al., 2018; Fecteau, 2018). The maximal turnaround time of 8 wk including fecal PCR and liquid culture enables testing of pregnant cows on MAP shedding during the dry period. This is of particular importance since a higher probability of MAP detection during the dry period in comparison to the subsequent lactation period has been described (Laurin et al., 2015). In addition, due to implementing quantitative real-time PCR assays for direct detection of MAP in feces or in fecal culture, high-, moderate-, and low-shedding cows can be detected. Even during a dry period shortened to 4 wk (Mansfeld et al., 2012), results of $\mathrm{PCR}$ and liquid culture are obtained before calving. This could be demonstrated by Schwalm et al. (2018), who detected even 95\% MAP-positive samples after $4 \mathrm{wk}$ and $97 \%$ after 6 wk of cultivation in liquid medium verified by PCR. Testing of pregnant cows before calving helps reduce neonatal MAP infections by offering the possibility of separating the calves right after birth from MAP-shedding dams and to feed colostrum from MAP-negative tested cows instead of the dam's colostrum.

\section{CONCLUSIONS}

In this study we present comparative data on detection of MAP in the field using fecal PCR and cultivation of MAP in liquid medium followed by real-time PCR for verification (liquid culture), emphasizing the benefits of rapidness, feasibility, and sensitivity of testing in dairy farms. For examination of paratuberculosis-suspected herds, rapid fecal PCR from boot swabs or individual samples is recommended to remove high shedders as soon as possible. For herds aiming to be nonsuspected of paratuberculosis, using liquid culture is recommended due to its higher sensitivity. The timing of both methods fits into the dry period management for gravid cows before birth, which is of particular importance for the reduction of infections in newborn calves.

\section{ACKNOWLEDGMENTS}

We thank Stefan Wörz (gerbion GmbH \& Co. KG) and Sandra Wiedmann (Chemical and Veterinary Investigations Office) for their support during laboratory studies. Our special thanks go to the Grimminger-Stif- tung für Zoonosenforschung (Stuttgart, Germany) for funding this project. gerbion $\mathrm{GmbH} \& \mathrm{Co}$. KG supplied the nucleic extraction kits and real-time PCR assay used in this study. The data were analyzed and evaluated independently without any inappropriate influence that bias the paper's content. None of the authors has any financial benefit resulting from this study.

\section{REFERENCES}

Al-Mamun, M. A., R. L. Smith, Y. H. Schukken, and Y. T. Grohn. 2017. Use of an Individual-based model to control transmission pathways of Mycobacterium avium ssp. paratuberculosis infection in cattle herds. Sci. Rep. 7:11845. https://doi.org/10.1038/s41598 $-017-12078-z$.

Bakker, D. 2014. The use of serology in the control of paratuberculosis. Page 38 in Proceedings of the 12th International Colloquium on Paratuberculosis, Parma, Italy, June 22-26, 2014.

Barkema, H. W., K. Orsel, S. S. Nielsen, A. P. Koets, V. Rutten, J. P. Bannantine, G. P. Keefe, D. F. Kelton, S. J. Wells, R. J. Whittington, C. G. Mackintosh, E. J. Manning, M. F. Weber, C. Heuer, T. L. Forde, C. Ritter, S. Roche, C. S. Corbett, R. Wolf, P. J. Griebel, J. P. Kastelic, and J. De Buck. 2018. Knowledge gaps that hamper prevention and control of Mycobacterium avium subspecies paratuberculosis infection. Transbound. Emerg. Dis. 65(Suppl 1):125-148. https://doi.org/10.1111/tbed.12723.

Collins, M. T., V. Eggleston, and E. J. Manning. 2010. Successful control of Johne's disease in nine dairy herds: Results of a six-year field trial. J. Dairy Sci. 93:1638-1643.

Donat, K., U. Schau, and A. Soschinka. 2011. Identification of Mycobacterium avium ssp. paratuberculosis infected dairy herds by environmental sampling. Berl. Munch. Tierarztl. Wochenschr. 124:360-367.

Donat, K., M. Schmidt, H. Kohler, and C. Sauter-Louis. 2016. Management of the calving pen is a crucial factor for paratuberculosis control in large dairy herds. J. Dairy Sci. 99:3744-3752. https:/ doi.org/10.3168/jds.2015-10625.

Eisenberg, T., W. Wolter, M. Lenz, K. Schlez, and M. Zschock. 2013. Boot swabs to collect environmental samples from common locations in dairy herds for Mycobacterium avium ssp. paratuberculosis (MAP) detection. J. Dairy Res. 80:485-489. https://doi.org/10 .1017/S002202991300040X.

Fecteau, M. E. 2018. Paratuberculosis in cattle. Vet. Clin. North Am. Food Anim. Pract. 34:209-222. https://doi.org/10.1016/j.cvfa .2017.10.011.

FLI (Friedrich-Loeffler-Institute, Federal Research Institute for Animal Health). 2016. Amtliche Methodensammlung Paratuberkulose (Mycobacterium avium ssp. paratuberculosis). Accessed Apr. 1, 2016. https://www.fli.de/en/publications/amtliche -methodensammlung/.

Fock-Chow-Tho, D., E. Topp, E. A. Ibeagha-Awemu, and N. Bissonnette. 2017. Comparison of commercial DNA extraction kits and quantitative PCR systems for better sensitivity in detecting the causative agent of paratuberculosis in dairy cow fecal samples. J. Dairy Sci. 100:572-581. https://doi.org/10.3168/jds.2016-11384.

Garvey, M. 2018. Mycobacterium avium subspecies paratuberculosis A possible causative agent in human morbidity and risk to public health safety. Open Vet. J. 8:172-181. https://doi.org/10.4314/ ovj.v8i2.10.

Hahn, N., K. Failing, T. Eisenberg, K. Schlez, M. Zschock, K. Donat, E. Einax, and H. Kohler. 2017. Evaluation of different diagnostic methods for the detection of Mycobacterium avium ssp. paratuberculosis in boot swabs and liquid manure samples. BMC Vet. Res. 13:259. https://doi.org/10.1186/s12917-017-1173-6.

Herthnek, D., and G. Bolske. 2006. New PCR systems to confirm realtime PCR detection of Mycobacterium avium ssp. paratuberculosis. BMC Microbiol. 6:87. https://doi.org/10.1186/1471-2180-6-87. 
Johansen, K. A., E. E. Hugen, and J. B. Payeur. 2006. Growth of Mycobacterium avium ssp. paratuberculosis in the presence of hexadecylpyridinium chloride, natamycin, and vancomycin. J. Food Prot. 69:878-883.

Laurin, E. L., M. Chaffer, J. T. McClure, S. L. McKenna, and G. P. Keefe. 2015. The association of detection method, season, and lactation stage on identification of fecal shedding in Mycobacterium avium ssp. paratuberculosis infectious dairy cows. J. Dairy Sci. 98:211-220. https://doi.org/10.3168/jds.2014-8406.

Liverani, E., E. Scaioli, C. Cardamone, P. Dal Monte, and A. Belluzzi. 2014. Mycobacterium avium subspecies paratuberculosis in the etiology of Crohn's disease, cause or epiphenomenon? World J. Gastroenterol. 20:13060-13070. https://doi.org/10.3748/wjg.v20 .i36.13060

Lombard, J. E. 2011. Epidemiology and economics of paratuberculosis. Vet. Clin. North Am. Food Anim. Pract. 27:525-535. https://doi .org/10.1016/j.cvfa.2011.07.012.

Lu, Z., R. M. Mitchell, R. L. Smith, J. S. Van Kessel, P. P. Chapagain, Y. H. Schukken, and Y. T. Grohn. 2008. The importance of culling in Johne's disease control. J. Theor. Biol. 254:135-146. https://doi .org/10.1016/j.jtbi.2008.05.008.

Mansfeld, R., C. Sauter-Louis, and R. Martin. 2012. Effects of dry period length on milk production, health, fertility, and quality of colostrum in dairy cows. Invited review. Tierarztl. Prax. Ausg. G Grosstiere Nutztiere 40:239-250.

Marcé, C., P. Ezanno, H. Seegers, D. U. Pfeiffer, and C. Fourichon. 2011. Within-herd contact structure and transmission of Mycobacterium avium subspecies paratuberculosis in a persistently infected dairy cattle herd. Prev. Vet. Med. 100:116-125. https://doi.org/10 .1016/j.prevetmed.2011.02.004.

Nielsen, S. 2009. Programmes on paratuberculosis in Europe. Pages 101-108 in Proceedings of 10th International Colloquium on Paratuberculosis, Minneapolis, MN, Aug. 9-13, 2009. International Association for Paratuberculosis. http://www.paratuberculosis.net/ proceedings/proc10.pdf.

Pierce, E. S. 2018. Could Mycobacterium avium subspecies paratuberculosis cause Crohn's disease, ulcerative colitis... and colorectal cancer? Infect. Agent. Cancer 13:1. https://doi.org/10.1186/ s13027-017-0172-3.

Plain, K. M., I. B. Marsh, A. M. Waldron, F. Galea, A. M. Whittington, V. F. Saunders, D. J. Begg, K. de Silva, A. C. Purdie, and R. J. Whittington. 2014. High-throughput direct fecal PCR assay for detection of Mycobacterium avium ssp. paratuberculosis in sheep and cattle. J. Clin. Microbiol. 52:745-757. https://doi.org/ 10.1128/JCM.03233-13.

Plain, K. M., A. M. Waldron, D. J. Begg, K. de Silva, A. C. Purdie, and R. J. Whittington. 2015. Efficient, validated method for detection of mycobacterial growth in liquid culture media by use of bead beating, magnetic-particle-based nucleic acid isolation, and quantitative PCR. J. Clin. Microbiol. 53:1121-1128. https://doi .org/10.1128/JCM.03521-14.

Pozzato, N., J. Gwozdz, M. Gastaldelli, K. Capello, C. Dal Ben, and E. Stefani. 2011. Evaluation of a rapid and inexpensive liquid culture system for the detection of Mycobacterium avium ssp. paratuberculosis in bovine faeces. J. Microbiol. Methods 84:413-417. https://doi.org/10.1016/j.mimet.2011.01.019.

Prendergast, D. M., R. A. Pearce, D. Yearsley, E. Ramovic, and J. Egan. 2018. Evaluation of three commercial PCR kits for the direct detection of Mycobacterium avium ssp. paratuberculosis (MAP) in bovine faeces. Vet. J. 241:52-57. https://doi.org/10 $.1016 /$ j.tvjl.2018.09.013.
Raizman, E. A., L. A. Espejo, and S. J. Wells. 2011. Long-term survival of Mycobacterium avium ssp. paratuberculosis in fecal samples obtained from naturally infected cows and stored at $-18^{\circ} \mathrm{C}$ and $-70^{\circ} \mathrm{C}$. Vet. Med. Int. 2011:341691. https://doi.org/10.4061/2011/ 341691

Raizman, E. A., S. J. Wells, S. M. Godden, R. F. Bey, M. J. Oakes, D. C. Bentley, and K. E. Olsen. 2004. The distribution of Mycobacterium avium ssp. paratuberculosis in the environment surrounding Minnesota dairy farms. J. Dairy Sci. 87:2959-2966.

Ramovic, E., D. Yearsley, E. NiGhallchoir, E. Quinless, A. Galligan, B. Markey, A. Johnson, I. Hogan, and J. Egan. 2019. Mycobacterium avium subspecies paratuberculosis in pooled faeces and dust from the housing environment of herds infected with Johne's disease. Vet. Rec. 184:65. https://doi.org/10.1136/vr.105085.

Reddacliff, L. A., A. Vadali, and R. J. Whittington. 2003. The effect of decontamination protocols on the numbers of sheep strain $M y-$ cobacterium avium ssp. paratuberculosis isolated from tissues and faeces. Vet. Microbiol. 95:271-282.

Schwalm, A. K., A. Obiegala, M. Pfeffer, and R. Sting. 2018. Enhanced sensitivity and fast turnaround time in laboratory diagnosis for bovine paratuberculosis in fecal samples. J. Microbiol Methods 152:39-47. https://doi.org/10.1016/j.mimet.2018.07.010.

Selim, A., and W. Gaede. 2012. Optimization of DNA extraction for identification of Mycobacterium avium ssp. paratuberculosis in faeces. Online J. Vet. Res. 16:163-171.

Sting, R., M. Hrubenja, J. Mandl, G. Seemann, A. Salditt, and S. Waibel. 2014. Detection of Mycobacterium avium ssp. paratuberculosis in faeces using different procedures of pre-treatment for realtime PCR in comparison to culture. Vet. J. 199:138-142. https:// doi.org/10.1016/j.tvjl.2013.08.033.

Timms, V. J., H. M. Mitchell, and B. A. Neilan. 2015. Optimisation of DNA extraction and validation of PCR assays to detect Mycobacterium avium ssp. paratuberculosis. J. Microbiol. Methods 112:99-103. https://doi.org/10.1016/j.mimet.2015.03.016.

Whittington, R. J. 2009. Factors affecting isolation and identification of Mycobacterium avium ssp. paratuberculosis from fecal and tissue samples in a liquid culture system. J. Clin. Microbiol. 47:614-622.

Whittington, R. J., I. Marsh, S. McAllister, M. J. Turner, D. J. Marshall, and C. A. Fraser. 1999. Evaluation of modified BACTEC 12B radiometric medium and solid media for culture of Mycobacterium avium ssp. paratuberculosis from sheep. J. Clin. Microbiol. $37: 1077-1083$.

Whittington, R. J., and E. S. Sergeant. 2001. Progress towards understanding the spread, detection and control of Mycobacterium avium subsp paratuberculosis in animal populations. Aust. Vet. J. 79:267-278.

Whittington, R. J., A. M. Whittington, A. Waldron, D. J. Begg, K. de Silva, A. C. Purdie, and K. M. Plain. 2013. Development and validation of a liquid medium (M7H9C) for routine culture of $M y$ cobacterium avium ssp. paratuberculosis to replace modified Bactec 12B medium. J. Clin. Microbiol. 51:3993-4000. https://doi.org/10 $.1128 / \mathrm{JCM} .01373-13$.

\section{ORCIDS}

A. K. Schwalm • https://orcid.org/0000-0003-4286-7190 